\title{
Tuberculosis among prison staff in Rio Grande do Sul
}

\author{
Tuberculose entre profissionais de penitenciárias do Rio Grande do Sul \\ Tuberculosis entre los profesionales de las prisiones en Rio Grande do Sul
}

\begin{abstract}
Caroline Busatto', Luciana de Souza Nunes", Andréia Rosane de Moura Valim"', Mariana Soares Valença ${ }^{\mathrm{IV}}$, Suzane Frantz Krug'III, Daniela Beckerv, Manuela Filter Allgayer'II, Lia Gonçalves Possuelo"I'

' Universidade de Santa Cruz do Sul, Pharmacy Course. Santa Cruz do Sul, Rio Grande do Sul, Brazil.

"Universidade Federal do Pampa, Medicine Course. Uruguaiana, Rio Grande do Sul, Brazil.

I" Universidade de Santa Cruz do Sul, Postgraduate Program in Health Promotion. Santa Cruz do Sul, Rio Grande do Sul, Brazil.

IV Universidade Católica de Pelotas, Center for Life Sciences and Health. Pelotas, Rio Grande do Sul, Brazil.

${ }^{\vee}$ Fundação Estadual de Produção e Pesquisa em Saúde, $13^{\text {th }}$ Regional Health Sector,

Public Health Regional Laboratory. Santa Cruz do Sul. Rio Grande do Sul, Brazil.
\end{abstract}

How to cite this article:

Busatto C, Nunes LS, Valim ARM, Valença MS, Krug SF, Becker D, et al. Tuberculosis among prison staff in Rio Grande do Sul. Rev Bras Enferm [Internet]. 2017;70(2):370-5. DOI: http://dx.doi.org/10.1590/0034-7167-2016-0012

Submission: 01-22-2016 Approval: 11-02-2016

ABSTRACT

Objective: to evaluate the risk of infection and illness caused by Mycobacterium tuberculosis among health care and security staff in prisons in two regions of Rio Grande do Sul (RS). Method: cross-sectional study involving prison staff. An interview and sputum smear microscopy and culture were performed. Latent infection was evaluated according to the result of the tuberculin test (TT), selfreferred. Results: among staff who had a TT, $10(83.3 \%)$ in the central region and $2(16.7 \%)$ in the southern region were considered reactors. Length of employment among prison officers who reacted to TT was 15.3 years, and among health care workers, 4.1 years $(p=0.01)$. No cases of active tuberculosis (TB) were identified. Conclusion: prevalence of latent TB was $27.9 \%$. Length of employment between different professional categories and their working regions was considered a risk factor for latent TB.

Descriptors: Tuberculosis; Latent Tuberculosis; Tuberculin Test; Prison; Staff.

\section{RESUMO}

Objetivo: avaliar o risco de infeç̧ão e adoecimento por Mycobacterium tuberculosis entre profissionais de saúde e de segurança em casas penitenciárias de duas regiões do Rio Grande do Sul (RS). Método: estudo transversal, envolvendo profissionais de penitenciárias. Foi realizada uma entrevista, baciloscopia e cultura de escarro. A infecção latente foi avaliada de acordo com o resultado do teste tuberculínico (TT), auto-referido. Resultados: entre os trabalhadores que realizaram o TT na região central, 10 $(83,3 \%)$ foram considerados reatores; e na região sul, $2(16,7 \%)$. O tempo de trabalho entre os agentes penitenciários reatores ao TT foi 15,3 anos e entre os trabalhadores da saúde 4,1 anos ( $p=0,01)$. Não foram identificados casos de Tuberculose (TB) ativa. Conclusão: a prevalência de TB latente foi $27,9 \%$. O tempo de trabalho entre as diferentes categorias profissionais e a região em que trabalham foram considerados fator de risco para TB latente.

Descritores: Tuberculose; Tuberculose Latente; Teste Tuberculínico; Presídio; Trabalhadores.

\section{RESUMEN}

Objetivo: evaluar el riesgo de infección y de la enfermedad por Mycobacterium tuberculosis entre los profesionales de la salud y seguridad en los centros penitenciarios en dos regiones del estado de Rio Grande do Sul (RS). Método: estudio transversal con la participación de profesionales de la prisión. Se llevó a cabo una entrevista, la baciloscopia y cultivo de esputo. La infección latente se evaluó de acuerdo con el resultado de la prueba de la tuberculina (TST) mediante auto-reporte. Resultados: entre los trabajadores que realizaron la TST en la región central, $10(83,3 \%)$ fueron considerados reactores; y $2(16,7 \%)$ en la región Sur. El tiempo de trabajo entre los agentes de la prisión con reacción a la TST fue de 15,3 años, y entre los trabajadores de la salud fue de 4,1 años $(p=0,01)$. No 
hubo casos identificados de la tuberculosis (TB) activa. Conclusión: la prevalencia de la TB latente fue del 27,9\%. El tiempo de trabajo entre las diferentes categorías profesionales y la región en la que trabajan fueron considerados factores de riesgo para la TB latente.

Descriptores: Tuberculosis; Tuberculosis Latente; Prueba de la Tuberculina; Prisión; Trabajadores.

\section{INTRODUCTION}

People working in environments with high prevalence of tuberculosis (TB) such as health institutions, drug treatment centers and prisons, particularly in low- and middle-income countries, are at higher risk of developing the disease. The latest estimates by the World Health Organization (WHO) reported nine million new TB cases in 2013 and 1.5 million deaths from TB worldwide, which are unacceptably high figures considering that most deaths are preventable and people have health care, diagnosis and adequate treatment provided free of charge ${ }^{(1-4)}$.

Regarding poor living conditions and compromised immune system, the following population groups are the most vulnerable to TB: indigenous populations, homeless people, people living with HIV/AIDS and persons deprived of liberty $(\mathrm{PDL})^{(5-6)}$. Brazil ranks fourth worldwide among countries with the largest prison population. There are several reasons why TB is highly endemic in Brazilian prisons: overcrowding, poorly ventilated cells, poor hygiene conditions, poor nutrition, high HIV prevalence, risk behaviors such as alcohol and drug use. Additional factors include irregular treatment and the late detection of cases of resistance, which contribute to the spread of intramural $\mathrm{TB}^{(7-9)}$.

Prevalence of latent infection among staff in a prison in Malaysia was $81 \%$, and $2.1 \%$ were considered respiratory symptomatic (RS). Active TB was excluded in all of them following care at the local hospital ${ }^{(1)}$. There is growing recognition that the high risk of TB in such environments is a problem not only for prisoners, but for society as a whole $\mathrm{e}^{(10)}$. In order to meet this challenge, prison workers are few in number and poorly paid, with precarious work contracts and high turnover ${ }^{(11)}$. In addition, these workers have contact with their families and the community, which means a great risk of double-contamination, i.e., an uncontrolled TB epidemic inside the prison can pose a serious risk to these contacts and society as a whole ${ }^{(12-13)}$.

In this context, the objective of this study was to evaluate the risk of infection and illness by $M$. tuberculosis among health care and safety staff in prisons in two distinct regions of Rio Grande do Sul, Brazil.

\section{METHOD}

\section{Ethical considerations}

The project was approved by the Research Ethics Committee (CEP) of the University of Santa Cruz do Sul (UNISC) and complies with all ethical principles set forth in resolution 466/12 of the Brazilian National Health Council. Each participating institution expressed its formal agreement to be part of the study. All activities were performed with the consent of the sites where the study was carried out and of the participants.

\section{Design, location of study and period}

A cross-sectional study was carried out among health care and security staff of four prisons in two distinct regions of the state of Rio Grande do Sul, involving four cities: Pelotas (southern region), Santa Cruz do Sul, Lajeado and Sobradinho (central region). Interviews were carried out with workers in the four prisons between February and July 2015. Pelotas Regional Prison (PRP), one of the largest in the South region of Brazil (Figure 1), has capacity for 472 inmates, but houses 1,050 prisoners. In 2013, prevalence of TB in the city of Pelotas was 67 cases/100,000 inhabitants; in the same period, prevalence inside the prison was 2,285/100,000. In the city of Santa Cruz do Sul, Santa Cruz do Sul Regional Prison (PRSC), one of the largest in the Rio Pardo valley, has capacity for 250 prisoners, but currently houses 437 inmates. TB prevalence among the city's population in 2013 was 91 cases/100,000 inhabitants, and inside PRSC this figure was 7,780/100,000. Santa Cruz do Sul and Pelotas are part of the group of priority municipalities for TB control in $\mathrm{RS}^{(14-16)}$.

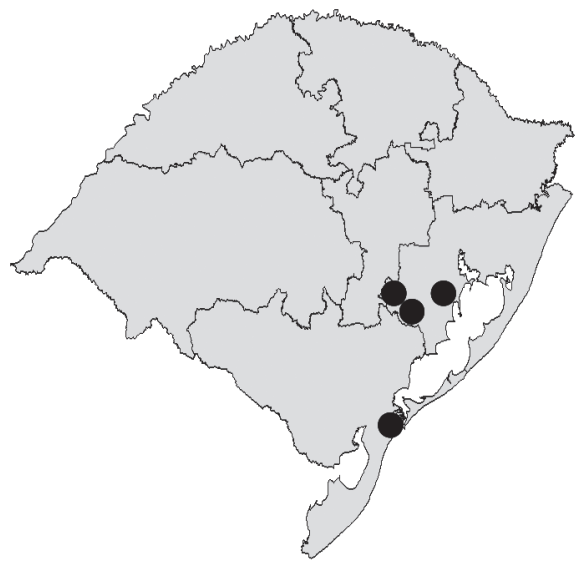

Figure 1 - Location of cities involved in the study, Brazil

Lajeado State Prison (PEL) is a medium-sized prison with capacity for 186 prisoners, and currently houses 531 inmates. TB prevalence in the city in 2013 was 37 cases/100,000 inhabitants, and inside the prison, 564/100,000. In Sobradinho State Prison (PES), a small prison, prevalence of TB cases among prisoners in 2013 was 980, while TB prevalence in the city was 105 cases/100,000 inhabitants. It has capacity for 130 prisoners, and the current of number of inmates is 102. Among the prisons in the study, it is the only one that is not overcrowded ${ }^{(14-16)}$.

\section{Sample}

The study included health care and security staff of the four prisons that agreed to participate in the project. The 
questionnaire was administered and test samples were collected during working hours.

\section{Study Protocol}

Sputum samples were collected from workers classified as RS, individuals presenting cough and sputum production for three or more weeks ${ }^{(17)}$ after the interview (Figure 2). Data were collected from staff who signed an informed consent form in a face-to-face structured questionnaire containing personwork information.

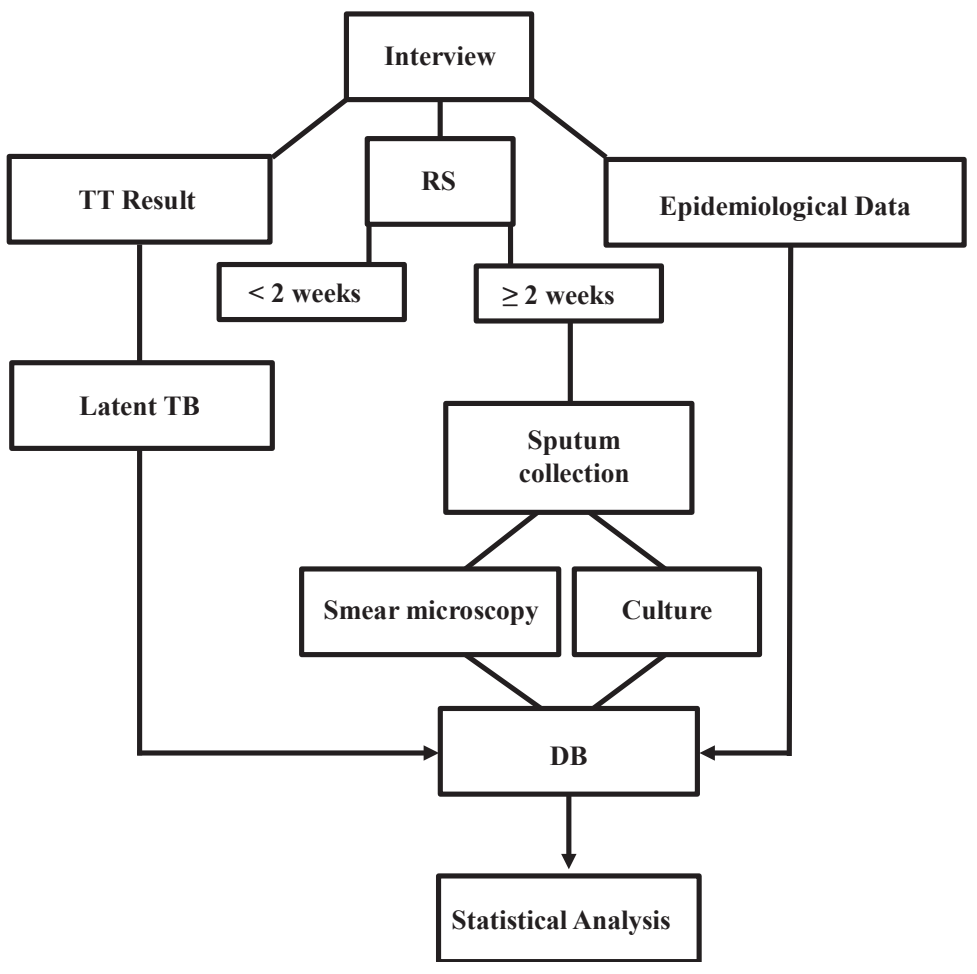

Note: ${ }^{*} D B=$ Database; $T T=$ Tuberculin Test; $R S=$ Respiratory Symptomatic; $T B=T u$ berculosis

Figure 2 - Data collection flow chart

The research instrument contains open and closed questions related to the epidemiological characteristics of workers, such as: age, gender (female/male), position (prison officer/ health care professional); length of employment at the prison; working hours in the facility (6 hours/8 hours/other); smoking habits (non-smoker, smoker, former smoker); previous Tuberculin Test (TT) (yes/no) and previous results (reactor or non-reactor); to diabetes mellitus (yes/no); previous TB history (yes/no); other lung diseases (yes/no).

After the interview, participants classified as RS collected two sputum samples, one at the time of the interview and the other on the following morning, which were analyzed by direct microscopic examination and culture for mycobacteria. The technique used for microscopy was detection of acid fast bacilli (AFB) by the Ziehl-Nielsen method $^{(14)}$. The culture test was performed by Ogawa-Kudoh culture medium ${ }^{(17)}$. The microbiological analyses were performed at the Laboratory of the $13^{\text {th }}$ Regional Health Sector of Santa Cruz do Sul, with the support of the Biological Research Institute - Central Laboratory of Public Health of Rio Grande do Sul (IPB/LACEN-RS).

\section{Analysis of results and statistics}

The analysis of the information contained in the administered questionnaires and of the laboratory data were tabulated in SPSS Program (v 20.0). For latent TB evaluation, TT results (reactor vs. non-reactor) were compared. For analysis of active TB, smear microscopy and culture results (positive vs. negative) were compared.

A preliminary analysis was performed using exploratory data techniques to verify the distribution patterns and trends of the main variables (absolute numbers, frequencies and means). Then, bivariate analyses were performed to verify the presence of associations between them. Chi-squared $\left(\mathrm{X}^{2}\right)$ tests were used for percentage differences and Student's t-tests for differences between means. To estimate associations with the presence of infection and disease by M. tuberculosis, odds ratio (OD) was used as a measure of association, estimated with a $95 \%$ confidence interval.

\section{RESULTS}

$47(41.22 \%)$ workers from the southern region and $67(58.77 \%)$ workers from the central region took part in the study, comprising 114 workers of a total of approximately $79.72 \%$ of working staff from the four prisons involved in the study.

Regardless of the region studied, frequency of male workers was higher $(58.1 \%)$. The most frequent age group of staff in both regions was 30-39 years. There was no difference between mean age (37.8 vs. 39.8 years) and length of employment (7.43 vs. 7.76 years) reported by participants from the central and southern regions, respectively ( $p$ $>0.05$ ) (Table 1). However, it was observed that length of employment was higher among prison officers (8.04 vs. 3.17 years, $p=0.01$ ), regardless of the region studied. More than $20 \%$ of workers in both regions reported having had some kind of lung disease, such as pneumonia.

Among the workers interviewed, 43 (37.7\%) reported having had a TT at some time since starting their professional activities in prisons. No association of working hours, length of employment and position with TT positivity was observed. Among staff members who had a TT, 10 (83.3\%) in the central region and $2(16.7 \%)$ in the southern region were considered reactors (Table 2 ). There was an association between TT positivity and region [OD $=6.6$ (1.3-50.9); $p<0.05]$. Analysis of mean length of employment by professional category showed that TT reactive prison officers had greater length of employment compared to health care workers (15.3 vs. 4.1 years) ( $p$ $=0.01)$, regardless of the region studied. 
Table 1 - Overall characteristics of prison staff

\begin{tabular}{|c|c|c|c|c|}
\hline & $\begin{array}{c}\text { Central } \\
\text { n (\%) }\end{array}$ & $\begin{array}{c}\text { Southern } \\
\text { n (\%) }\end{array}$ & $\begin{array}{l}\text { Total } \\
\text { n (\%) }\end{array}$ & $p^{*}$ \\
\hline \multicolumn{5}{|l|}{ Gender } \\
\hline Female & $27(57.4)$ & $20(42.6)$ & $47(41.2)$ & \multirow[t]{2}{*}{0.84} \\
\hline Male & $40(59.7)$ & $27(57.4)$ & $67(58.8)$ & \\
\hline \multicolumn{5}{|l|}{ Age Group } \\
\hline $18-29$ years & $14(73.7)$ & $5(26.3)$ & $19(16.7)$ & \multirow[t]{4}{*}{0.34} \\
\hline $30-39$ years & 29 (56.9) & $22(43.1)$ & $51(44.7)$ & \\
\hline $40-49$ years & $17(60.7)$ & $11(39.3)$ & $28(24.6)$ & \\
\hline$>50$ years & $7(43.8)$ & $9(56.2)$ & $16(14.0)$ & \\
\hline \multicolumn{5}{|l|}{ Length of employment } \\
\hline $0-10$ years & $43(58.1)$ & 31 (41.9) & 74 (64.9) & \multirow{3}{*}{0.83} \\
\hline $10-20$ years & $16(57.1)$ & $12(42.9)$ & 28 (24.6) & \\
\hline$>20$ years & $8(66.7)$ & $4(33.3)$ & $12(10.5)$ & \\
\hline \multicolumn{5}{|l|}{ Position } \\
\hline Prison Officer & $57(60.6)$ & 37 (39.4) & $94(82.5)$ & \multirow[t]{2}{*}{0.45} \\
\hline Health Care Worker** & $10(50)$ & $10(50.0)$ & $20(17.5)$ & \\
\hline \multicolumn{5}{|l|}{ Previous Tuberculosis } \\
\hline Yes & $1(50)$ & $1(50.0)$ & $2(1.8)$ & \multirow[t]{2}{*}{1.00} \\
\hline No & $66(58.9)$ & $46(41.1)$ & $112(98.2)$ & \\
\hline \multicolumn{5}{|l|}{ Smoker } \\
\hline Yes & $6(50.0)$ & $6(50.0)$ & $12(10.5)$ & \multirow{2}{*}{0.17} \\
\hline No & $61(59.8)$ & $41(40.2)$ & $102(89.5)$ & \\
\hline \multicolumn{5}{|l|}{ Diabetes } \\
\hline Yes & $2(66.7)$ & $1(33.3)$ & $3(2.6)$ & 1.00 \\
\hline \multicolumn{5}{|l|}{ Other lung disease } \\
\hline Yes & $14(60.9)$ & $9(39.1)$ & $23(20.2)$ & \multirow[t]{2}{*}{1.00} \\
\hline No & $53(58.2)$ & $38(41.8)$ & $91(79.8)$ & \\
\hline \multicolumn{5}{|l|}{ Tuberculin test } \\
\hline Yes & $22(51.2)$ & $21(48.8)$ & $43(37.7)$ & \multirow[t]{2}{*}{0.43} \\
\hline No & 45 (63.4) & $26(36.6)$ & $71(62.3)$ & \\
\hline
\end{tabular}

Note: *Chi-squared; **Health Care Worker: social worker, oral health assistant, dentist, nurse, auxiliary nurse, psychologist.

Table 2 - Comparison of workers' characteristics with Tuberculin Test results

\begin{tabular}{|c|c|c|c|c|}
\hline & $\begin{array}{l}\text { Reactor } \\
\text { n (\%) }\end{array}$ & $\begin{array}{c}\text { Non-reactor } \\
\text { n (\%) }\end{array}$ & $\begin{array}{l}\text { Total } \\
\text { n (\%) }\end{array}$ & $\boldsymbol{p}^{*}$ \\
\hline $\begin{array}{l}\text { Gender } \\
\text { Female } \\
\text { Male }\end{array}$ & $\begin{array}{l}7(38.9) \\
5(20.0)\end{array}$ & $\begin{array}{l}11(61.1) \\
20(80.0)\end{array}$ & $\begin{array}{l}18(41.9) \\
25(58.1)\end{array}$ & 0.30 \\
\hline $\begin{array}{l}\text { Workload } \\
\quad 8 \text { hours } \\
>8 \text { hours }\end{array}$ & $\begin{array}{l}4(26.7) \\
8(28.6)\end{array}$ & $\begin{array}{l}11(73.3) \\
20(71.4)\end{array}$ & $\begin{array}{l}15(34.9) \\
28(65.1)\end{array}$ & 1.00 \\
\hline $\begin{array}{l}\text { Length of employr } \\
0-10 \text { years } \\
11-20 \text { years } \\
>20 \text { years }\end{array}$ & $\begin{array}{l}5(21.7) \\
5(35.7) \\
2(33.3)\end{array}$ & $\begin{array}{l}18(78.3) \\
9(64.3) \\
4(66.7)\end{array}$ & $\begin{array}{c}23(53.5) \\
14(32.6) \\
6(14.0)\end{array}$ & 0.62 \\
\hline $\begin{array}{l}\text { Position } \\
\text { Prison Officer } \\
* * \text { Health Care } \\
\text { Worker }\end{array}$ & $\begin{array}{l}9(26.5) \\
3(33.3)\end{array}$ & $\begin{array}{c}25(73.5) \\
6(66.7)\end{array}$ & $\begin{array}{c}34(79.1) \\
9(20.9)\end{array}$ & 0.69 \\
\hline $\begin{array}{l}\text { Region } \\
\text { Central } \\
\text { Southern }\end{array}$ & $\begin{array}{c}10(83.3) \\
2(16.7)\end{array}$ & $\begin{array}{l}13(41.9) \\
18(58.1)\end{array}$ & $\begin{array}{l}23(53.5) \\
20(46.5)\end{array}$ & $0.035 \#$ \\
\hline
\end{tabular}

Note: *Chi-squared; \#Fischer's exact test; **Health Care Worker: social worker, oral health assistant, dentist, nurse, auxiliary nurse, psychologist.
Of the $18(15.8 \%)$ staff members considered as RS, 11 (61.1\%) were from the central region and 7 (38.9\%) from the southern region. Thirteen of the RS workers (11.4\%) agreed to have smear microscopy and culture tests, none of which was positive.

\section{DISCUSSION}

TB incidence in the cities where the study was carried out is variable $(37.79$ to $92.35 / 100,000)$. Some of these cities are priority for TB control ${ }^{(14-16)}$. The number of cases of the disease in the city reflects the high incidence within the overcrowded prisons, as described in other studies carried out with workers of high-incidence prisons, which poses an occupational hazard for the people who work there ${ }^{(1,18)}$. The hypothesis that the southern region would have a higher incidence of TB for having the largest prison involved in the study was not confirmed. Prevalence of latent TB among workers was higher in the central region.

In our study, prevalence of latent TB was $27.9 \%$, and only $37.7 \%$ of workers taking part in the study had already had a TT at some time since starting their professional activities in prisons. These data do not reflect the reality observed in other prisons in Brazil and the world. In a study carried out in the largest penitentiary in Malaysia, a middle-income country with an intermediate incidence of TB (82/100,000 inhabitants) ${ }^{(19)}$, an $81 \%$ prevalence of TT positivity was identified among office staff, health care workers and prison officers ${ }^{(1)}$. In Brazil, a study carried out in two prisons in São Paulo evaluated the prevalence of latent TB using TT. The authors found that $57.3 \%$ of staff had TT $>10 \mathrm{~mm}$, and that among the contacts of TB patients the figure was $62.4 \%$ of the total ${ }^{(20)}$. In the United States, a study to identify latent TB testing practices among security workers in 1,760 randomly selected jails found that $52 \%$ of jails had a policy for latent TB testing among security professionals and only $51 \%$ performed annual screening. Considering the high risk of TB in prisons, annual and pre-employment tests should be performed, including TT and chest X-ray, in all professionals working with PDL, such as health care workers, prison officers and teachers ${ }^{(17)}$. However, we observed that the number of professionals who reported having had a TT was low, which reflects the lack of regular testing and the need for a more efficient policy to monitor the health of these professionals. In a study carried out in Rio Grande do Sul with the nursing staff of a university hospital, the authors observed a prevalence of $47.3 \%$ of latent TB among those professionals, which reinforced the need for occupational health control measures for the regular screening of these workers ${ }^{(21)}$.

In the evaluation concerning the detection of active TB, no cases were identified. These data are in agreement with those described in a study carried out in São Paulo ${ }^{(20)}$. The frequency of workers who reported previous TB was $1.8 \%$, but no supporting documentation was found. In other studies, in regions with intermediate TB incidence, the frequency of cases of workers reporting previous TB ranged from $0.7 \%$ to $1.2 \%^{(1,20)}$. It is known that prison staff are a conduit for TB transmission from prisons to their respective communities ${ }^{(1)}$. Such data are reinforced by a study carried out in Brazil in which $54 \%$ of M. tuberculosis isolates circulating in the community were the same as those in the prison $^{(22)}$. The high frequency of male staff in prisons is due to the 
existence of a greater percentage of male offenders, and, in addition, a prisoner can only be supervised by an officer of the same gender ${ }^{(23)}$. Studies described in the literature report a frequency of male workers inside prisons ranging between $80 \%$ and $90 \%(1,20)$. In our study, we found a lower frequency of male staff $(58.1 \%)$. This may be related to the inclusion of health care workers, who are mostly women. The most prevalent age group was 30-39 years $(44.7 \%)$, with a mean age of 38.6 years. These data corroborate those presented by Nogueira et al. $(2008)^{(20)}$.

Smoking is common in prisons, both among PDL and workers, and is considered a risk factor for infection and active disease. It is a major obstacle to global TB control(1). Al-Darraji et al. (2015) reported that more than half of the participants $(56.4 \%)$ reported using tobacco ${ }^{(1)}$. In our study, $10.5 \%$ of the workers were smokers, data that agree with those from São Paulo prisons $(25.3 \%)^{(20)}$.

In a study carried out in $2015^{(1)}$, the authors identified that prison staff with more than 12 months of activity inside prisons were five times more likely to be TT reactors compared to those in employment for less than 12 months. Analysis of mean length of employment by professional category revealed that the mean length of employment of prison officers with reaction to TT was three times higher compared to health care workers.

\section{Study limitations}

We identified rotating shift schedules as a hindrance to interviewing all prison staff, besides the fact that TT results were self-reported and not performed as pre-employment screening, influencing the low prevalence of latent infection observed. There is a lack of national and international scientific production on the prevalence of active and latent TB among prison workers, especially in the South region of Brazil.

\section{Contributions to the area of nursing, health or public policy}

This study demonstrates the need to target actions carried out by TB control programs towards PDL and professional staff in prisons, since such facilities have high incidence and prevalence rates of the disease, reflected in increased transmission to the community.

\section{CONCLUSION}

Prevalence of latent TB was $27.9 \%$ and no cases of active TB were identified. Length of employment between different professional categories was considered a risk factor for latent TB. The frequency of TT positivity in workers in the central region was six times higher compared to workers in the southern region of the state. TB is a difficult disease to control due to its great transmissibility in indoor environments, such as prisons. Therefore, it is essential to establish routines and work flows for pre-employment and regular testing of prison workers together with state and municipal TB control programs.

\section{FUNDING}

Brazilian Ministry of Science, Technology and Innovation/ National Council for Scientific and Technological Development, process MCTI/CNPq/UNIVERSAL 14/2014 and the Education and Technology Diffusion Program/State Foundation for Production and Research in Health, process PADCT/ FEPPS/2014. National Council for Scientific and Technological Development (CNPq) - Scientific Initiation grant (process 125968/2014-0).

\section{REFERENCES}

1. Al-Darraji HAA, Tan C, Kamarulzaman A. Prevalence and correlates of latent tuberculosis infection among employees of a high security prison in Malaysia. Occup Environ Med[Internet]. 2015[cited 2015 Jul 07];72(6):442-7. Available from: https://www. ncbi.nlm.nih.gov/pmc/articles/PMC4625842/pdf/nihms684878.pdf

2. World Health Organization. Global Tuberculosis Report[Internet]. 2013[cited 2015 Sep 08]; Available from: http://apps.who.int/iris/bitstr eam/10665/91355/1/9789241564656_eng.pdf

3. World Health Organization. Global Tuberculosis Report[Internet]. 2014[cited 2015 Sep 13]; Available from: http://apps.who.int/iris/bitstr eam/10665/137094/1/9789241564809_eng.pdf

4. Sacchi PCF, Praça RM, Tatara MB, Simonsen V, Ferrazoli L, Croda MG. Prisons as Reservoir for Community Transmission of Tuberculosis, Brazil. Emerging Infectious Diseases[Internet]. 2015[cited 2015 Oct 02];21(3):452-5. Available from: http://www.ncbi.nlm.nih.gov/pmc/ articles/PMC4344267/pdf/14-0896.pdf

5. Pinto ML, Silva CT, Gomes FCL, Bertolozzi RM, Villavicencio MML, Azevedo AFMK, et al. Ocorrência de casos de tuberculose em Crato, Ceará, no período de 2002 a 2011: uma análise espacial de padrões pontuais. Rev Bras Epidemiol[Internet]. 2015 [cited 2015 Jul 23];18(2):313-25. Available from: http://www.scielosp.org/pdf/rbepid/v18n2/pt_1415-790X-rbepid-18-02-00313.pdf

6. Estevan AO, Oliveira SMVL, Croda J. Active and latent tuberculosis in prisoners in the Central-West Region of Brazil. Rev Soc Bras Med Trop[Internet]. 2013[cited 2015 Jul 15];46(4):515-8. Available from: http://www.scielo.br/pdf/rsbmt/v46n4/0037-8682-rsbmt-00-00-17.pdf

7. Sànchez AR, Larouzé B, Diuana V. Controle de tuberculose nas prisões brasileiras: novas abordagens para um antigo problema. Cad Saúde Pública[Internet]. 2010[cited 2015 Jul 22];26(5):850-1. Available from: http://www.scielosp.org/pdf/csp/v26n5/01.pdf

8. Alcantara LM, Alves RS, Oliveira RCC, et al. Ações para controle da Tuberculose no sistema penitenciário masculino. Rev Enferm UFPE[Internet]. 2014[cited 2015 Jul 20];8(11):3832-32. Available from: http://www.revista.ufpe.br/revistaenfermagem/index.php/ 
revista/article/download/6679/10745

9. Brasil. Ministério da Saúde. Secretaria de Vigilância em Saúde. Boletim Epidemiológico[Internet]. 2014[cited 2015 Jul 10];44(2):1-13. Available from: http://www.vigilanciaemsaude.ba.gov.br/sites/default/files/Boletim-Tuberculose-2014.pdf

10. Carbone ASS, et al. Active and latent tuberculosis in Brazilian correctional facilities: a cross-sectional study. BMC Infect Dis[Internet]. 2015[cited 2015 Sep 04];15(24):1-8. Available from: http://bmcinfectdis.biomedcentral.com/articles/10.1186/s12879-015-0764-8

11. Coninx R, Maher D, Reyes H, Grzemska M. Tuberculosis in prisons in countries with high prevalence. BMJ[Internet]. 2000 [cited 2015 Jul 20];320(1):440-2. Available from: http://www.ncbi.nlm.nih.gov/pmc/articles/PMC1117551/pdf/440.pdf

12. Bick JA. Infection Control in Jails and Prisons. Clinical Infectious Diseases[Internet]. 2007[cited 2015 Jul 04];45(8):1047-55. Available from: http://cid.oxfordjournals.org/content/45/8/1047.full.pdf + html

13. Ferreira JS, Oliveira HB, Marin-Léon L. Conhecimento, atitudes e práticas sobre tuberculose em prisões e no serviço público de saúde. Rev Bras Epidemiol[Internet]. 2013[cited 2015 Aug 03];16(1):100-113. Available from: http://www.scielo.br/pdf/rbepid/v16n1/1415-790Xrbepid-16-01-0100.pdf

14. Brasil. Ministério da Saúde. Sistema de Informação de Agravos de Notificação (SINAN). Tuberculose: casos confirmados notificados no Sistema de Informação de Agravos de Notificação - SINAN Net[Internet]. 2012[cited 2015 Jul 13]. Available from: http://200.198.173.165/scripts/deftohtm.exe?snet/tubercrsnet

15. SES-RS. Secretaria estadual de Saúde: Programa estadual de controle da tuberculose. Porto Alegre: SES[Internet]. 2010 [cited 2015 Jun 28] Available from: http://www.saude.rs.gov.br/lista/210/Tuberculose

16. SUSEPE. Departamento de Segurança e Execução Penal. [Internet]. 2015[cited 2015 May 31]. Available from: http://www.susepe. rs.gov.br/conteudo.php?cod menu=1

17. Brasil. Manual de Recomendações para o Controle da Tuberculose no Brasil. Brasília: Ministério da Saúde[Internet]. 2011 [cited 2015 May 30]. Available from: http://portalpbh.pbh.gov.br/pbh/ecp/files.do?evento=download\&urlArqPlc=manual recomendacoes TB11.pdf

18. Binswanger LA. Tuberculosis testing in correctional officers: a national random survey of jails in the United States. Int J. Tuberc Lung Dis[Internet]. 2010[cited 2015 Jul 12];14(4):464-70. Available from: http://www.ingentaconnect.com/content/iuatld/ ijtld/2010/00000014/00000004/art00015

19. World Health Organization. Global Tuberculosis Report[Internet]. 2012[cited 2015 Sep 08]. Available from: http://apps.who.int/iris/bitstr eam/10665/75938/1/9789241564502 eng.pdf

20. Nogueira AP, Abrahão MCMR, Galesi NMV. Infecção tuberculosa latente em profissionais contatos e não contatos de detentos de duas penitenciárias do Estado de São Paulo, Brasil, 2008. Rev Bras Epidemiol[Internet]. 2011[cited 2015 May 30];14(3):486-94. Available from: http://www.scielo.br/pdf/rbepid/v14n3/13.pdf

21. Severo KG, Oliveira JS, Carneiro M, Valim AR, Krummenauer EC, Possuelo LG. Latent tuberculosis in nursing professionals of a Brazilian hospital. J Occup Med Toxicol[Internet]. 2011 [cited 2015 Jul 10];17(1):6-15. Available from: https://occup-med.biomedcentral.com/articles/10.1186/1745-6673-6-15

22. Sacchi FP, Praça RM, Tatara MB, Simonsen V, Ferrazoli L, Croda MG, Suffys PN, Ko AI, Andrews JR, Croda J. Prisons as reservoir for community transmission of tuberculosis, Brazil. Emerg Infect Dis[Internet]. 2015[cited 2015 Aug 12];21(3):452-5. Available from: http://www.ncbi.nlm.nih.gov/pubmed/25642998

23. Santos SAT. Os Sentidos do Trabalho para os Agentes Penitenciários: Uma Análise na Cadeia Pública de Salvador. Rev Forma: Viv Est[Internet]. 2014[cited 2015 Jun 18];7(2):19-34. Available from: http://www.seer-adventista.com.br/ojs/index.php/formadores/article/ view/506 